\title{
INTESTINAL INTUSSUSCEPTION AND OCCLUSION CAUSED BY SMALL BOWEL POLYPS IN THE PEUTZ- JEGHERS SYNDROME. MANAGEMENT BY COMBINED INTRAOPERATIVE ENTEROSCOPY AND RESECTION THROUGH MINIMAL ENTEROSTOMY: CASE REPORT
}

Joaquim J. Gama-Rodrigues, José Hyppolito da Silva, Adilson A. Aisaka, Ricardo Jureidini, Renato Falci Júnior, Fauze Maluf Filho, Chong A. Kim, André Wan Wen Tsai and Cláudio Bresciani

GAMA-RODRIGUES J et al. - Intestinal intussusception and occlusion by small bowel polyps in the Peutz-Jeghers syndrome. Management by combined intraoperative enteroscopy and resection through minimal enterostomy: case report. Rev. Hosp. Clín. Fac. Med. S. Paulo 55(6):219-224, 2000.

The Peutz-Jeghers syndrome is a hereditary disease that requires frequent endoscopic and surgical intervention, leading to secondary complications such as short bowel syndrome. Case report: This paper reports on a 15-year-old male patient with a family history of the disease, who underwent surgery for treatment of an intestinal occlusion due to a small intestine intussusception. Discussion: An intra-operative fiberscopic procedure was included for the detection and treatment of numerous polyps distributed along the small intestine. Enterotomy was performed to treat only the larger polyps, therefore limiting the intestinal resection to smaller segments. The postoperative follow-up was uneventful. Conclusion: We point out the importance of conservative treatment for patients with this syndrome, especially those who will undergo repeated surgical interventions because of clinical manifestation while they are still young.

DESCRIPTORS: Peutz-Jeghers syndrome-therapy. Intussusception. Intestinal polyps. Literature review.

The Peutz-Jeghers syndrome is a hereditary disturbance characterized by gastrointestinal polyposis associated with a characteristic mucocutaneous pigmentation, primarily at lips, oral, and gingival mucosae. Jeghers and colleagues initially established the PeutzJeghers syndrome as a nosocomial entity in $1949^{16}$. It is not rare; several cases have been reported ${ }^{1,10,14,29,33}$ after the first description by Peutz in $1921^{25,31}$.

Among the most common complications of the intestinal polyposis is in- testinal invagination or intussusception, which is a frequent cause for emergency services and an indication for laparotomy and enterectomy ${ }^{19}$. However, in the last decade, with the progress of endoscopic equipment and techniques that have made enteroscopy with polypectomy possible, this method has been used with the objective of avoiding intestinal resection in

From the Department of Gastroenterology, Hospital das Clínicas, Faculty of Medicine, University of São Paulo. the patients with Peutz-Jeghers syndrome $e^{7,15,22,24}$. The objective of the present report is to support the therapeutic approach that combines endoscopic and surgical methods during laparotomy in the treatment of the intestinal occlusion for polyps in the Peutz-Jeghers syndrome, in order to avoid resection of intestinal segments.

\section{REPORT OF THE CASE}

A 15-year-old white male, who, at age 11 , was diagnosed with Peutz- 
Jeghers syndrome with associated intestinal polyposis and cutaneous lentiginosis (Fig. 1 and 2), was referred to our unit complaining of vomiting around 30 minutes after meals for the previous 6 months. He also complained about colicky pain in the epigastric area and loss of $1.5 \mathrm{~kg}$ in that 6-month period. He reported a previous endoscopic removal of dozens of polyps from the stomach, duodenum, and colon. He also reported a similar illness in his father and in 1 of 2 sisters (Fig. 3 ). His paternal grandfather presented suggestive symptoms of the syndrome; however the diagnosis of the disease was not confirmed in him.

The patients weight was $32 \mathrm{~kg}$ and height was $1.55 \mathrm{~m}$ (both below the 2.5 percentile range for the age). He presented hyperchromic macules on the hands (Fig. 1), oral mucosa, and characteristic pigmentation in the lips (Fig. 2 ). He presented moderate systolic pan cardiac murmurs.

The laboratory analysis confirmed microcytic and hypochromic anemia.

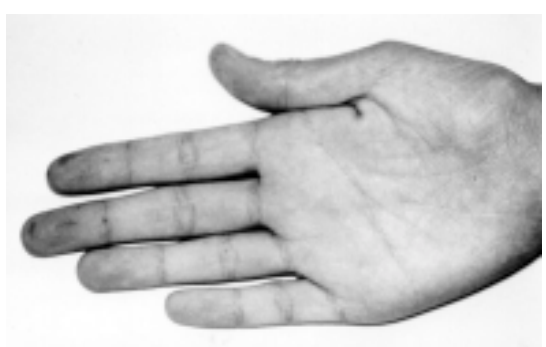

Figure 1 - Characteristic cutaneous pigmentation of Peutz-Jeghers syndrome in the hands.

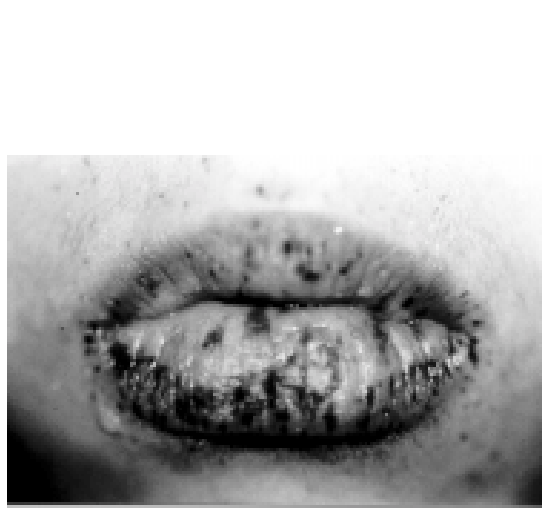

Figure 2 - Characteristic pigmentation in the lips.
The whole digestive tube underwent imaging investigation (Barium swallow, endoscopy, and colonoscopy). They showed:

- Normal esophagus;

- Stomach: several sessile polyps in the gastric body, with diameters ranging from 3 to $6 \mathrm{~mm}$, whose histological analysis revealed hyperplastic polyp (Fig. 4);

- Duodenum: polyps similar to those found in the stomach, however some of them were hamartomatous and others were hyperplastic;

- Small intestine: image of an "onion peel", suggestive of intussusception next to the Treitz angle, as well as micro polyps in the terminal ileum (Fig. 5);

- Normal large intestine.

With the diagnosis of intestinal subocclusion with intussusception, the patient underwent enterotomy combined with intra-operative enteroscopy. At laparotomy, 2 intussusception areas were confirmed - one in the proximal jejunum and the other in the terminal ileum. Both were reduced. The introduction of fiberscopic equipment (EG 290I Pentax), sterilized with glutaraldehyde, by enterotomy enabled the study of the entire small intestine, proximal and distal to the jejunum incision (Fig. 6). After the introduction of the equipment by the enterotomy, 9 polyps were found and excised: 2 through enterotomy and 7 by endoscopy. Biopsy revealed that all of the polyps, which varied from 5 to $30 \mathrm{~mm}$ at the largest axis, were hamartomatous (Fig. 7).

With such a procedure, further enterectomy was avoided because complete endoscopic investigation of the small intestine and the resection of all the polyps of that segment had been accomplished.

The patient had a normal recovery and was sent home in the third postoperative day. Currently, he is under outpatient follow-up, is in good clinical condition and is gaining weight and growing.

\section{DISCUSSION}

Peutz-Jeghers syndrome is an autosomal dominant disease characterized by hamartomatous polyposis throughout the gastrointestinal tract, as well as mucocutaneous lentiginosis, mostly on

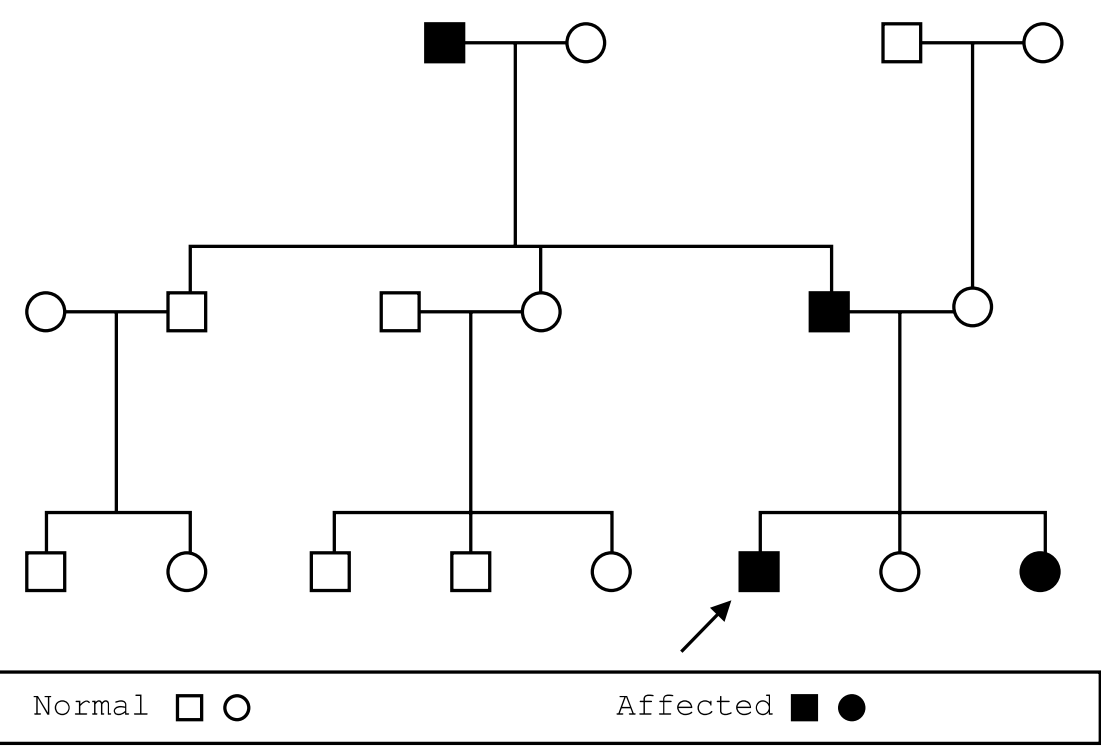

Figure 3 - Pedigree: The arrow indicates the described patient. 


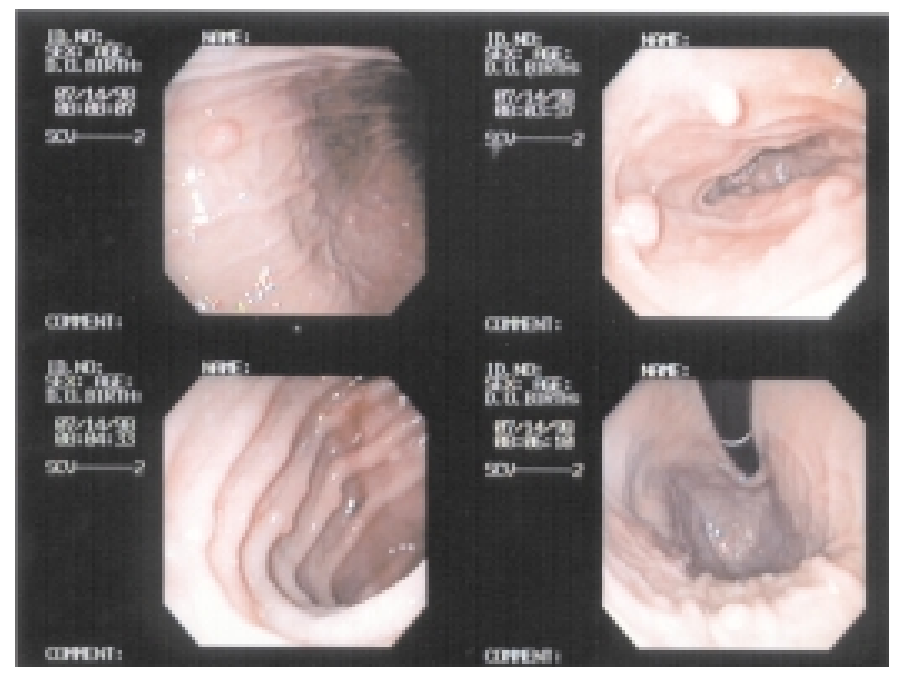

Figure 4 - Endoscopic view of sessile polyps in stomach.

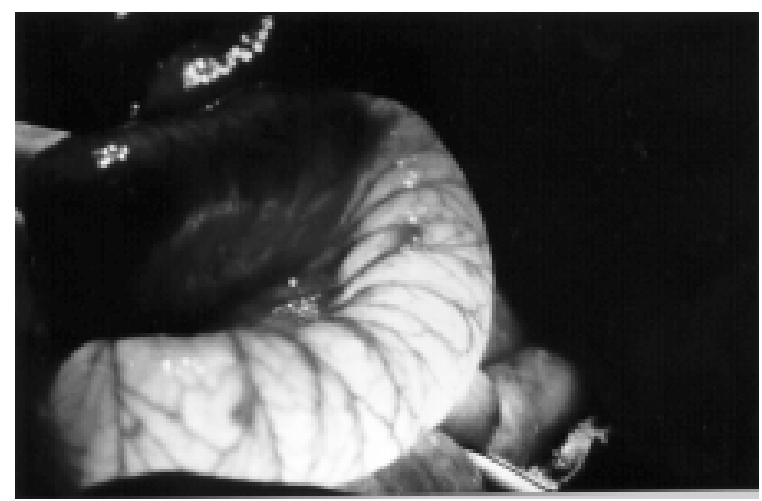

Figure 6 - Enteroscopy performed during laparotomy detected the polipys in small intestine.

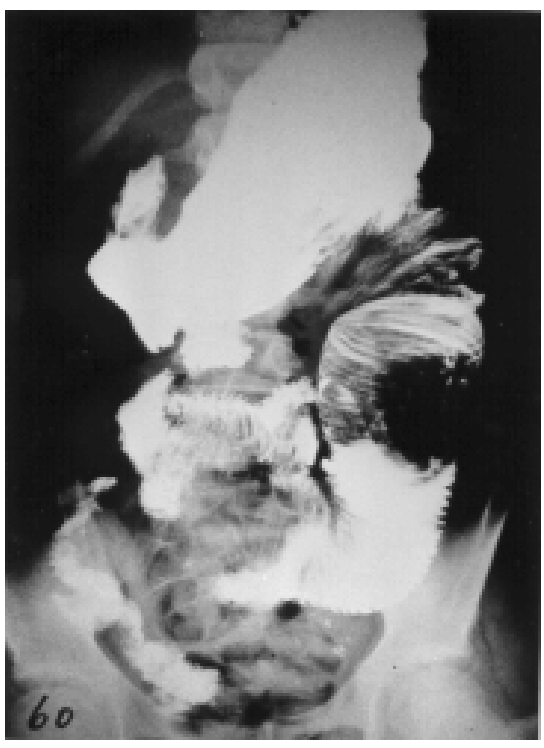

Figure 5 - Radiograph-barium meal image suggestive of intussusception.

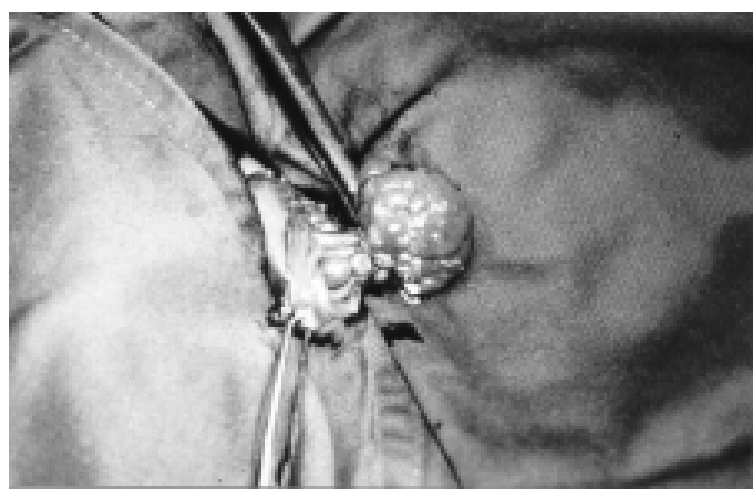

Figure 7 - Polyp of small intestine being resected through enterotomy. the lips, oral, and gingival muco$\mathrm{sae}^{4,12,13}$. However, it can also attack eyelids, fingers, hands, back, and sole, and, less frequently, the lumbar-sacral area and perineum ${ }^{16}$. The morbidity of the syndrome is due primarily to lesions of the small intestine ${ }^{7,29}$ that generally demand repeated enterectomies, leading eventually to small bowel syndrome $^{9,30}$. Because of the facility of endoscopic polypectomy in these segments of the digestive tube-even the stomach and colon, which are most frequently affected ${ }^{4,27}$ - this procedure rarely leads to complications ${ }^{26}$.

In Peutz-Jeghers syndrome, the polyps that appear in the gastrointesti- nal tract are almost always hamartomatous and are of multiple sizes, sessile, or pedunculated ${ }^{11}$; however some of these are associated with hyperplastic and adenomatous polyps ${ }^{3,11}$.

Concerning clinical evolution there is a high frequency of proteic-caloric malnutrition and anemia; a significant number of patients present obstruction of gastrointestinal tract secondary to pre-pyloric gastric polyps or, more frequently to small intestine polyps. In addition, repeated resection of the small intestine progressively decreases the capacity to absorb nutrients ${ }^{5}$.

Considering the need for a minimally aggressive treatment in these patients, and because the disease is almost always benign and is manifested throughout the digestive tract, the endoscopic method plays an important role in the therapeutic approach ${ }^{15,18,22,26}$. It enables the exact diagnosis of the lesions, as well as the resection of small gastric, duodenal, and colonic polyps. Through the combination of the surgical and endoscopic methods, it is possible to study and manipulate the entire small intestine, restricting enterectomy to segments with complications related to the polyps: intussusception with ischemia and perforation during the endoscopic resection, among others $^{7,18,28,29}$. 
Concerning the combined endoscopic and surgical approach, some authors prefer to introduce the endoscope through the mouth or anus, or both, after lysis of adhesions ${ }^{28}$, while others opt for introduction of the sterilized endoscope by enterotomy ${ }^{20}$, both with the same objective. The latter was the technique preferred in this case, which enabled the detection of the polyps without extensive resection of a small intestine loop. It was of great interest to avoid major resection of the bowel, since the patient is young and presented multiple lesions widely distributed among jejunum and ileum loops.

Another aspect in patients with Peutz-Jeghers syndrome is the associated occurrence or progression of in- testinal and extraintestinal malignant neoplasm. The frequency of malignant intestinal neoplasm in these patients is higher than in the general population 4,6,8,13,17,21,23,32; however, it has not yet been proved whether the neoplastic lesions are due to transformation of hamartomatous polyps ${ }^{2,3}$, to adenomatous polyps that appear together with the other polyps, or to de novo malignant lesions in normal mu$\operatorname{cosa}^{3,8,29}$. In brief, the surgical treatment of a patient with Peutz-Jeghers syndrome is reserved for treatment of complications of the polyposis of the digestive tract—obstruction and bleeding - as well as for accurate differential diagnosis of polypoid lesions that are malignant or with potential to be malignant. Endoscopic detection and resection of polyps combined with surgery seems to be the best approach to treat Peutz-Jeghers polyposis.

\section{CONCLUSION}

In Peutz-Jeghers syndrome with wide involvement of the small bowel, the combination of endoscopic resection of polyps during the surgical procedure avoids major intestinal resection and enables the removal of the intestinal polyps. The combination of the surgical and enteroscopic methods creates the possibility of preventing small bowel syndrome, as well as mapping the location of the numerous polyps and treating them during the same procedure.
GAMA-RODRIGUES JJ e col. Intussuscepção intestinal e oclusão intestinal causada por pólipos em intestino delgado na síndrome Peutz-Jeghers. Tratamento com ressecção por enterotomia associado a enteroscopia intraoperatória: relato de caso Rev. Hosp. Clín. Fac. Med. S. Paulo 55(6):219-224, 2000.
A síndrome de Peutz-Jeghers é uma doença de caráter hereditário que freqüentemente requer intervenções endoscópicas e cirúrgicas repetidas, levando a complicações secundárias como, por exemplo, a síndrome do intestino curto. Relato de caso: Relatamos neste artigo o caso de paciente de 15 anos, masculino, com história familiar para a doença, que foi subme- tido ao procedimento cirúrgico para tratar oclusão devido a intussucepção de intestino delgado. Discussão: Associou-se método fibroscópico intraoperatório com a finalidade de detecção e ressecção de numerosos pólipos distribuídos em todo o intestino delgado. Realizaram-se enterotomias para a retirada dos pólipos maiores, restringindo-se, portanto, a ressecção 
intestinal a segmentos menores. A evolução clínica foi boa. Conclusão: Ressalta-se a importância do manejo de forma conservadora dos pacientes portadores desta síndrome, principalmente naqueles cujas manifestações clínicas de importância cirúrgica aparecem precocemente.
DESCRITORES: Peutz-Jeghers. Síndrome-terapia. Intussucepção. Pólipos intestinais. Revisão da literatura.

\section{REFERENCES}

1. ANYANWU SN - Sporadic Peutz-Jeghers syndrome in a Nigerian. Cent Afr J Med 1999; 45 (7): 182-4.

2. BEYER AR - Carcinoma in situ arising in a gastric hamartomatous polyp in a patient with Peutz-Jeghers syndrome. Endoscopy 1996; 28:267.

3. BOSMAN FT - The hamartoma-adenoma-carcinoma sequence. J Pathol 1999; 188 (1): 1-2.

4. CHOI HS, PARK YJ \& PARK JG - Peutz-Jeghers syndrome: a new understanding. J Korean Med Sci 1999; 14 (1): 2-7.

5. DE FACQ L, DE SUTTER J, DE MAN M et al. - A Case of PeutzJeghers syndrome with polyposis, extreme iron deficiency anemia, and hamartoma-adenoma transformation: management by combined surgical and endoscopic approach. Am J Gastroenterol 1995; 90: 1330-2.

6. ENTIUS MM \& WESTERMAN AM - Molecular and phenotypic markers of hamartomatous polyposis syndrome in the gastrointestinal tract. Hepatogastroenterology 1999; 46 (26): 661-6.

7. EUGENE C, TENNENBAUM R, FINGERHUT A et al. - Traitement des tumeurs du grêle du syndrome de Peutz-Jeghers: Intérêt d'une approche combinée, endoscopique et chirurgicale. A propos de 2 cas familiaux, dont l'un suivi 15 ans. Gastroenterol Clin Biol 1992; 16: 604-7.

8. FLAGEOLE H, RAPTIS S, TRUDEL JL et al. - Progression toward malignancy of hamartomas in a patient with Peutz-Jeghers syndrome: a case report and literature review. Can J Surg 1994; 37: 231-6.

9. FOLEY TR, MCGARRITY TJ \& ABT AB - Peutz-Jeghers syndrome: a clinicopathologic survey of the "Harrisburg family" with a 49year follow up. Gastroenterology 1988; 95: 1535-40.

10. HABR-GAMA A, GAMA-RODRIGUES JJ, WARDE PJ et al. Síndrome de Peutz-Jeghers. Apresentação de dois casos. Arq Gastroent S Paulo 1974; 12: 53-62.

11. HABR-GAMA A \& CAMPOS FG - Síndromes polipóides do intestino grosso. In: PINOTTI H W - Tratado de clínica cirúrgica do aparelho digestivo. São Paulo, Atheneu 1994. p. 1253-4.

12. HATNED RK, BUCK JL \& SOBIN LH - The hamartomas polyposis syndromes: clinical and radiologic features. Review article. AJR 1995; 164: 565-71.

13. HEMMINKI A - The molecular basis and clinical aspects of PeutzJeghers syndrome. Cell Mol Life Sci 1999; 55 (5): 735-50.
14. IGUN GO, AMEH YY \& AWANI KU - Peutz-Jeghers syndrome: case report. East Afr Med J 1999; 76 (5): 284-286.

15. ISHIDA H, AMEH YY, AWANI KU et al. - A new simple technique for performing intraoperative endoscopic resection of small-bowel polyps in patients with Peutz-Jeghers syndrome. Surg Today 1999; 29 (6): 581-3.

16. JEGHERS H, MCKUSICK VA \& KATZ KH - Generalized intestinal polyposis and melanin spots of the oral mucosa, lips and digits: A syndrome of diagnostic significance. N Engl J Med 1949; 241: 933-1031.

17. JIANG CY, ESUFALI S, BERK T et al. - STK11/LKb1 germline mutation are not identified in most Peutz-Jeghers syndrome patients. Clin Genet 1999; 56 (2): 136-41.

18. KESHTGAR AS, LOSTY PD, LLOYD DA et al. - Recent developments in the management of Peutz-Jeghers syndrome in childhood. Eur J Pediatr Surg 1998; 7 (6): 367-8.

19. KILGUS M, RATHLIN MA \& LARGIADER F - Intussusception of the small bowel due to Peutz-Jeghers syndrome: a case report. Hepatogastroenterology 1998; 45: 454-5.

20. LAU WY, FAN ST, CHU KW et al. - Intra operative fiberoptic enteroscopy for bleeding lesions of small intestine. Br J Surg 1986; 73:217-8.

21. MCGARRIT YT, KULIN HE \& ZAINO RJ - Peutz-Jeghers syndrome. Am J Gastroenterol. 2000; 95 (3): 596-604.

22. PENNAZIO M \& ROSSINI FP - Small bowel polyps in Peutz-Jeghers syndrome: management by combined plush enteroscopy and intraoperative enteroscopy. Gastrointest Endosc 2000; 51 (3): 2048.

23. PETERSEN VC, SHEEHAN AL, BRYAN RL et al. - Misplacement of dysplastic epithelium in Peutz-Jeghers Polyps: the ultimate diagnostic pitfall. Am Surg Pathol 2000; 24 (1): 34-9.

24. PETROIANU A - Perioperative enteroscopy. Rev Paul Med 1997; 115: $1373-5$.

25. PEUTZ JLA - A very peculiar familial polyposis of the mucous membrane of the digestive tract and the nasopharynx together with peculiar pigmentation of the skin and mucous membran. Ned Maandschr Geneeskd 1921;10: 134.

26. ROSSINI FP, RISIO M \& PENNAZIO M - Small bowel tumors and polyposis syndromes. Gastrointest Endosc Clin N Am 1999; 9 (1): $39-114$. 
27. SETTAF A, MANSORI F, BARGACH S et al. - Syndrome de PeutzJeghers avec dégénérescence carcinomateuse d'un polype hamartomateux duodénal. Ann Gastroenterol Hepatol 1990; 26: 285-8.

28. SPIGELMAN AD, THOMSOM JPS \& PHILLIPS RKS - Toward decreasing the re-laparotomy rate in Peutz-Jeghers syndrome: the role of perioperative small bowel endoscopy. Br J Surg 1990; 77: 301-2.

29. UTSUNOMIYA J, GOCHO H, MIYANAGA T et al. - Peutz-Jeghers syndrome: Its nature course and management. Johns Hopk Med Hosp J 1975; 71-82.

30. VAN COEVORDEN, MATHUS-VLIEGEN EMH \& BRUMELKAMP WH - Combined endoscopic and surgical treatment in PeutzJeghers syndrome. Surg Gynecol Obstet 1986; 162: 26-8.
31. WESTERMAN AM, ENTIUS MM, DE BARR E et al. - Peutz-Jeghers syndrome: 78-year follow-up of the original family. Lancet 1999; 353 (9160): 1211-5.

32. WESTERMAN AM \& WILSON JH - Peutz-Jeghers syndrome: risk of a hereditary condition. Scand J Gastroenterol (Suppl) 1999; 230: 64-70.

33. YOSHIKAWA A, KURAMOTO S, MIMURA T et al. - Peutz-Jeghers syndrome manifesting complete intussusception of the appendix and associated with a focal cancer of the duodenum and a cystadenocarcinoma of the pancreas: report of a case. Dis Colon Rectum 1998; 41 (4): 517-21.

Received for publication on the $08 / 09 / 00$. 